\title{
省エネルギー・低環境負荷プロセスによるナノマテリアル創製と機能開発 Development of Nanomaterials with Energy-saving Green Processes and their Applications
}

\author{
増田 佳丈 \\ Yoshitake MASUDA \\ (独) 産業技術総合研究所
}

National Institute of Advanced Industrial Science and Technology

次世代を担う根幹科学領域としてバイオインスパイアード 材料科学への期待が一層の強まりを見せています. 自然界に おける永い営みが築き上げた持続可能型プロセスの価值が, 高い注目を浴びています. 例えば, 生物は, 体内などの水溶 液環境において, 金属酸化物などの精緻なナノ・マイクロ構 造体を作り上げています。これらは, 省エネルギー, 低環境 負何, 常温, 常圧, 省廃棄物, 周辺元素の利用などの利点を 有して扔り,これからの材料・デバイス開発の指針を示すも のです、新規ナノマテリアル創製の観点からも, 水溶液プロ セスなどの次世代科学は高い魅力を示しており, 結晶成長制 御や自己組織化, 有機・無機・バイオ材料のハイブリッド化 などを駆使することにより, 革新的な新規マテリアルが創出 されています. 本特集では, 低環境負荷プロセスを機軸とし た材料開発に関して, 広く議論が行われました。特に, セラ ミックスを始めとする種々の無機材料, 金属材料, ハイブ リッド材料などの先端材料に関して, 溶液プロセスなどによ る材料開発と, そのデバイス展開について, 先端の知見を共 有する学術・技術交流の場となりました. 当日の講演題目と 発表者を紹介いたします。

特別講演:「水に分散可能な無機クラスターを活用した水溶 液プロセスによる蛍光体の合成」(東北大学多元物質科学研 究所 $) \bigcirc$ 垣花 貪人, 佐藤 泰史, 小林亮, 加藤 英樹, 招待講演： 「遷移金属酸化物ナノ結晶の均一かつ不規則な集積およびその 剥離による単層ナノドットの合成」(慶応義塾大学理工学部) ○緒明 佑哉, 今井宏明,「MM-SPS プロセスで創製した純マ グネシウムの特性」(日大生産工) ○久保田 正広, (日大院生 産工, 現; 東芝プラントシステム)萩野敏基, 「腐食合成法を 用いた La-Al-Zr 系複合酸化物の作製」(室蘭工大院) ○釜澤 亮, (室蘭工大) 長船 康裕, 世利 修美, 招待講演 :「クリーン エネルギー・環境浄化のための機能性無機結晶および薄膜の ネイチャーミメティックフラックス創成」(信州大学工学部 環境機能工学科) ○手嶋勝弥, 我田 元, 是津 信行, 大石 修
治, 「Precipitation of $\mathrm{CeO}_{2}$ nanoparticles on $\mathrm{Al}_{2} \mathrm{O}_{3}$ and $\mathrm{BN}$ powder by rotary chemical vapor deposition」(IAREO, Tohoku Univ.) $\bigcirc$ Jianfeng ZHANG, (IMR, Tohoku Univ.)Takashi GOTO, 「ゾルーゲル法により合成したラメラ状ポリシルセスキオキサ ン層間へのエチレンオキシド鎖のグラフト反応」(早稲田大) ○大下 浩範, 奈良 洋希, 間間 聰之, 逢坂 哲彌, 菅原 義之, (モンペリエ第 2大) Borary BRURY, Ahmad MEHDI, 招待講 演：「階層構造を持つ酸化亜鉛粉体の合成」(独)物質・材料 研究機構) ○齋藤 紀子, 松本 研司, 渡邊 賢, 橋口未奈子, 坂口勲, 羽田肇,「カルボキシル基を持つ有機物の添加によ るスピンスプレ一酸化带鉛膜の作製」(東工大) ○杉本 直樹, 洪 正洙, 勝又健一, 岡田清, 松下伸広, 「細菌由来酸化鉄 を前駆体として作製した多孔質酸性非晶質シリカの特徵」 (岡大) ○橋本 英樹, (京大) 板谷篤司, (岡大) 工藤孝幸, 黒 田 泰重, 妹尾 昌治, (倉敷芸科大) 草野 圭弘, (生産開発科 学研究所) 池田 靖訓, (岡大) 中西 真, 藤井 達生, 高田潤, 「フェライトナノシートインクを用いたインクジェットパター ニング」 (東工大) ○高橋俊幸, 牧之瀬佑旗, 勝又健一, 岡 田清, 松下伸広, 「赤色発光を示すカルシウム系シリケート 蛍光体の合成と発光特性評価」(東北大多元研) ○佐藤 泰史, 加藤 英樹, 小林 亮, (成均館大新素材工) 正木 孝樹, (東北 大多元研)垣花 眞人, 招待講演:「チタン酸ナノチューブブラ シを用いた吸着性超撥水膜の作製」(大阪府立大学) ○高橋 雅 英, 岡田 健司, 徳留 靖明,「ハイブリッド噴霧法による層状 珪酸塩ナノ中空粒子の創製」(物材機構) ○皆川和己, 山田 裕 久, 田村 堅志, 招待講演 :「水溶液プロセスによる酸化スズ ナノマテリアル開発と応用」(独) 産業技術総合研究所) 増田 佳丈.

本号の特集においては, これらの発表の中から総説, 解説 が収録されています. 本領域のさらなる発展により，持続可 能型社会の実現, 産業競争力の強化, 次世代を担う学術領域 の進展が期待されます. 